\title{
What do we know about China's covid-19 vaccines?
}

chrisbaraniuk@gmail.com Cite this as: BMJ 2021;373:n912 http://dx.doi.org/10.1136/bmj.n912 Published: 09 April 2021

\section{The country where covid-19 first emerged is championing a string of vaccines, both domestically and abroad. But opacity surrounding data makes for a fractured picture, reports Chris Baraniuk}

Chris Baraniuk

\section{What vaccines has China developed?}

There are about a dozen Chinese vaccine candidates for covid-19, but five front runners have received emergency use approval in China as well as several other countries.

Sinopharm, a state owned enterprise, is currently working on two different jabs, both of which are based on an inactivated form of SARS-CoV-2. The first was developed at Sinopharm's Beijing institute while the second was developed in Wuhan. A third vaccine called CoronaVac was developed by the Beijing based pharmaceutical firm Sinovac. It is also based on an inactivated form of SARS-CoV-2.

All three of these require two doses but the fourth front runner, from vaccine developer CanSinoBIO, is single dose. Unlike the others, it uses a human adenovirus, Ad5, to deliver SARS-CoV-2 proteins into the body. (Russia's Sputnik V vaccine also uses a form of $\mathrm{Ad}_{5}$ as well as another adenovirus.) CanSinoBIO previously used the same approach to develop an Ebola vaccine that was approved for emergency use in China.

A fifth vaccine candidate, ${ }^{1}$ from pharmaceutical firm Anhui Zhifei Longcom, was given emergency use approval on 16 March. This one requires three doses and uses proteins based on the receptor binding domain of the SARS-CoV-2 virus.

All five of these vaccines can be kept at normal fridge temperatures, a big advantage over others that require storage at extremely cold temperatures.

\section{What clinical trial data are there?}

Randomised, double blinded phase I and II trial results for CoronaVac in two age groups $-18-59$ and 60 and over-were published in the Lancet in November ${ }^{2}$ and February, ${ }^{3}$ respectively. The trials found immunogenicity in most patients and that the vaccine was generally safe and well tolerated, with few adverse effects. Phase I and II data for the Anhui Zhifei Longcom vaccine published in March ${ }^{4}$ showed similar results.

At the time of writing, no phase III trial data for any of the Chinese vaccine candidates have been published in a peer reviewed journal. CanSinoBIO has said it intends to but has given no timeframe.

Most of what we know comes from announcements from the manufacturers and the governments in countries where trials are being conducted.

Sinopharm claimed in December that its first vaccine was $79 \%$ effective in terms of preventing symptomatic covid-19, based on interim phase III data. ${ }^{5}$ That is lower than the $86 \%$ efficacy reported earlier the same month by the United Arab Emirates, ${ }^{6}$ one of the countries in which the vaccine has been trialled. Other countries trialling the jab include Bahrain, Egypt, Jordan, and Peru. Sinopharm has also said its second vaccine, from the Wuhan institute, was found to be slightly less effective at $72.5 \%$, based on interim data from phase III trials. ${ }^{7}$

Also in December, Turkish officials reported interim data from trials showing that Sinovac's CoronaVac was $91.25 \%$ efficacious at preventing symptomatic covid-19 among a subgroup of 1322 participants in a trial involving 7371 people. ${ }^{8}$ But in January, researchers in Brazil announced that the CoronaVac jab was $78 \%$ effective at preventing mild cases, according to information from a phase III trial involving 12 ooo healthcare workers in the country. ${ }^{9}$ Just a week later, additional data emerged, taking into account very mild cases and suggesting that the vaccine was only $50.4 \%$ effective against symptomatic covid-19..$^{10}$ In the same month, authorities in Indonesia said the vaccine, which is being trialled there too, was $65 \%$ effective. ${ }^{11}$

CanSinoBIO's one dose jab was found to be $75 \%$ effective in Pakistan, according to officials there. ${ }^{12}$ The vaccine is also being trialled in Argentina, Chile, Mexico, and Russia. ${ }^{13}$

The Associated Press has reported that, according to preliminary data sent to China's drug regulators, Sinovac is safe for children aged 3 to 17 based on early and mid-stage trials of over 550 subjects. ${ }^{14}$

\section{How much do they cost?}

In December, state media in China reported that Sinopharm and Sinovac intended to charge the government roughly $\$ 30\left(€_{22} ; € 26\right)$ per dose of their vaccines. ${ }^{15}$ Detail about the cost of other vaccines developed in China has not been made public.

\section{How are the vaccines being deployed in China?}

All five of the leading domestic candidates can be used in China, though it's unclear how many doses of each have been administered so far, or where. No other vaccines have been approved for use in China.

The country had administered around 120 million doses as of 31 March, according to data published by the National Health Commission and reported by Reuters. ${ }^{16}$ Zhong Nanshan, a former president of the Chinese Medical Association, told the news agency in early March that China is aiming to vaccinate $40 \%$ of its 1.4 billion population by the end of July. ${ }^{17}$ The country is prioritising 18 to 59 year olds in key worker groups, such as healthcare workers, before moving 
on to clinically vulnerable people and then those who are aged 60 or over. ${ }^{18}$

Authorities behind Hong Kong's mass free vaccination programme have said that three centres originally set to offer the Pfizer vaccine would switch to Sinovac in response to strong public demand to be vaccinated as soon as possible.

Because of the lack of transparency surrounding Chinese made vaccines, however, vaccine hesitancy appears to be a problem. A survey by China's disease control and prevention centre found that just $42 \%$ of healthcare and epidemic preparedness workers were willing to have a vaccine during a recent rollout. ${ }^{19}$ There are reports of similar hesitancy in Brazil; in a recent poll in the country, just $47 \%$ of respondents said they would be willing to take a vaccine made in China. ${ }^{20}$

\section{Which of China's vaccines have been approved outside of China?}

Sinopharm's first vaccine has received the most emergency use approvals so far, nearly 30, including in Bahrain, Guyana, Hungary, Serbia, and the UAE. Hungary was the first EU country to approve use of a Chinese vaccine, with Prime Minister Viktor Orbán among those who have received it.

Several countries have approved Sinovac's CoronaVac jab for emergency use, including Brazil, Chile (where the vaccine has been trialled), Indonesia, Laos, Mexico, and Turkey.

Mexico and Pakistan have given emergency use approval to the CanSinoBIO vaccine.

The Anhui Zhifei Longcom vaccine has received approval for use in Uzbekistan.

\section{Which countries have received Chinese vaccines?}

Chinese firms have appeared keen to supply countries with plenty of doses of their vaccines, beyond those merely required to carry out clinical trials. For example, 223 million doses of Sinopharm jabs have already been distributed to various countries around the world. In some countries, the value of deals remains undisclosed but the New York Times reported that Hungary paid \$36 per dose for the Sinopharm jab. ${ }^{21}$ In Senegal, a lower price was achieved ${ }^{22}$-just $\$ 19$ per dose in a deal supplying 200000 Sinopharm doses to the African country.

Some nations are relying heavily on Chinese vaccines for their covid-19 vaccination programmes. The majority of those administered by the UAE, for example, are made by Sinopharm. Serbia looks set to receive another 500 ooo Sinopharm doses, having already taken delivery of 1.5 million. Cambodia and Egypt have received shipments of 300 ooo doses at a time.

Meanwhile, countries trialling Sinovac's vaccine have received large numbers of doses already. Indonesia, for instance, has had 28 million doses at the time of writing. Chile has received five shipments according to China's state media ${ }^{23}$ although the exact number of doses is unclear.

Rollout of the CanSinoBIO vaccine has only just started, but Pakistan has ordered "tens of millions" of doses, according to its health minister. ${ }^{24}$ Mexico has ordered eight million doses of the same jab.

Commissioned, not peer reviewed

Competing interests: None.
Wu H. China approves another covid-19 vaccine for emergency use. AP. 16 March 2021 https://apnews.com/article/science-biology-clinical-trials-microbiology-coronavirus-pandemic25b1d6227a0921038a0dbded2c7dfb6c.

2 Zhang Y, Zeng G, Pan H, et al. Safety, tolerability, and immunogenicity of an inactivated SARS-CoV-2 vaccine in healthy adults aged 18-59 years: a randomised, double-blind, placebo-controlled, phase 1/2 clinical trial. Lancet Infect Dis 2021;21:181-92 doi: 10.1016/S1473-3099(20)30843-4 pmid: 33217362

3 Wu Z, Hu Y, Xu M, et al. Safety, tolerability, and immunogenicity of an inactivated SARS-CoV-2 vaccine (CoronaVac) in healthy adults aged 60 years and older: a randomised, double-blind, placebo-controlled, phase 1/2 clinical trial. Lancet Infect Dis 2021:S1473-3099(20)30987-7. doi: 10.1016/S1473-3099(20)30987-7. pmid: 33548194

$4 \quad$ Yang S, Li Y, Dai L, et al. Safety and immunogenicity of a recombinant tandem-repeat dimeric RBD-based protein subunit vaccine (ZF2001) against COVID-19 in adults: two randomised, double-blind, placebo-controlled, phase 1 and 2 trials. Lancet Infect Dis 2021;24:S1473-3099(21)00127-4. doi: 10.1016/S1473-3099(21)00127-4. pmid: 33773111

5 Sinopharm's covid-19 vaccine 79\% effective, seeks approval in China. Reuters. 30 December 2020. www.reuters.com/article/health-coronavirus-china-vaccine-int-idUSKBN2940CA.

6 Kerr S, Shepherd C. Covid vaccine from China's Sinopharm is $86 \%$ effective, says UAE. Financial Times. 9 December 2020. www.ft.com/content/1ef92350-3519-4522-9f80-94eec14fa588.

7 Baptista E. Covid-19 vaccines made by China's Sinopharm, CanSino release efficacy data. South China Morning Post. 24 February 2021. www.scmp.com/news/china/science/article/3122980/covid-19-vaccines-made-chinas-sinopharm-cansino-release-efficacy.

8 Zimmer C, Londono E. Turkey and Brazil say Chinese vaccine effective, with sparse supporting data. New York Times. 25 December 2020. www.nytimes.com/2020/12/25/health/turkey-brazilsinovac-coronavirus-vaccine.html.

9 Cohen J, Moutinho S. Brazil announces "fantastic" results for Chinese-made covid-19 vaccine, but details remain sketchy. Science2021. www.sciencemag.org/news/2021/01/brazil-announces fantastic-results-china-made-covid-19-vaccine-details-remain-sketchy.

10 Sinovac: Brazil results show Chinese vaccine 50.4\% effective. BBC News. 13 January 2021. www.bbc.co.uk/news/world-latin-america-55699535.

11 Soeriaatmadja W. Indonesia grants emergency use approval to Sinovac's vaccine, local trials show 65\% efficacy. Straits Times. 12 January 2021. www.straitstimes.com/asia/se-asia/indonesiagrants-emergency-approval-for-sinovac-vaccine.

12 China's 1-dose covid-19 vaccine 74.8\% effective in late-stage trial. CGTN. 9 February 2021. https://news.cgtn.com/news/2021-02-09/CanSinoBIO-s-COVID-19-vaccine-74-8-effective-inPakistan-trials-XJrVtCspNu/index.html.

13 Phase III trial of a covid-19 vaccine of adenovirus vector in adults 18 years old and above. Clinicaltrials.gov. https://clinicaltrials.gov/ct2/show/NCT04526990.

14 Wu H. Sinovac says its vaccine is safe for children as young as 3. AP. 23 March 2021. https://apnews.com/article/clinical-trials-coronavirus-pandemic-china-coronavirus-vaccine-taiwanfb94301994153e07f8c5ca259a996607.

15 Government to pay 200 yuan per dose of Chinese covid-19 inactivated vaccines. Global Times. 16 December 2020. www.globaltimes.cn/content/1210093.shtml.

16 China administered total of $119.82 \mathrm{mln}$ doses of covid-19 vaccines as of March 31. Reuters. 1 April 2021. www.reuters.com/article/health-coronavirus-china-vaccine/china-administered-totalof-119-82mln-doses-of-covid-19-vaccines-as-ofmarch-31-idUSB9N2LHOOQ.

17 China aims to vaccinate 40\% of population by end-July: senior adviser. Reuters. 2 March 2021. www.reuters.com/article/us-health-coronavirus-china-vaccine-idUSKBN2AU0J9.

18 Davidson H, Standaert M. New year, new outbreak: China rushes to vaccinate 50 million as holiday looms. Guardian. 15 January 2021. www.theguardian.com/global-development/2021/jan/15/new-year-new-outbreak-china-rushes-to-vaccinate-50-million-as-holidayseason-looms.

19 Lew L. China's public hesitant to take covid-19 vaccines, another survey suggests. South China Morning Post. 19 February 2021. www.scmp.com/news/china/science/article/3122418/chinaspublic-hesitant-take-covid-19-vaccines-another-survey.

20 Vaccine refusal in Brazil grows to 22\%, most reject Chinese shot: poll. Reuters. 12 December 2020. www.reuters.com/article/us-health-coronavirus-brazil-idUSKBN28MOVC.

21 Wee SI, Novak B. Hungary pays big for a Chinese vaccine. New York Times. 12 March 2021. www.nytimes.com/2021/03/11/world/hungary-sinopharm-covid.html.

22 Ba D. Senegal pays $\$ 3.7 \mathrm{mln}$ for 200000 doses of China's Sinopharm vaccine. Reuters. 12 February 2021. www.reuters.com/article/health-coronavirus-senegal-vaccine-idUSL8N2KI4AU.

23 Chile receives 5 th shipment of Chinese Sinovac vaccine against covid-19. Xinhua. 9 March 2021 www.xinhuanet.com/english/2021-03/09/__139796671.htm.

24 Shahzad A. Pakistan approves Chinese CanSinoBIO covid vaccine for emergency use. Reuters. 12 February 2021. www.reuters.com/article/us-health-coronavirus-pakistan-vaccineidUSKBN2AC1FG.

This article is made freely available for use in accordance with BMJ's website terms and conditions for the duration of the covid-19 pandemic or until otherwise determined by BMJ. You may use, download and print the article for any lawful, non-commercial purpose (including text and data mining) provided that all copyright notices and trade marks are retained. 